\title{
THE REASONS FOR INCREASING EMPLOYMENT DEMAND IN THE PUBLIC SECTOR IN TURKEY
}

\author{
Abdulkerim Yavuzaslan \\ PhD Student, Szent István University
}

\begin{abstract}
The economic changes taking place in the world and in Turkey, have led to changes in people's employment demand. Before 2000 government jobs had been considerably less attractive in Turkey, after 2000, when the economic crisis occurred in Turkey public employment demands started to increase. One of the reasons for this that a growing number of people have started to face the unemployment situation that made the formerly less desired public employment more alluring. Beyond employment security there have been also reasons Turkish people choosing to work for government. The goal of this paper how employment demand of Turkish people is changing. Based on last few decade's employment data the paper, will try to shed some light on the reasons behind the related new labor market tendencies.
\end{abstract}

Keywords: Working Life, Career, Employment

\section{Introduction}

The economical fluctuations in the world and especially in Turkey has dramatically changed the demand regarding work force. Once it was not so popular to work in the public sector, the reason for this was the lower incomes and the stabilized average salaries in terms of earning money in the public fields. Therefore employees were mostly willing to work in the private sector to earn more money.

Employees found themselves in a situation in which they intentionally retreated not to lose their current job because of the competition, the diminishing number of companies, stabilization of salaries, shrinking of the fields of demand and the economical crisis. There are several triggering reasons why people are willing to work in the public sector today. The Turkish legislation clearly shows in the 49th amendment of the constitution that the employees are supported by the government itself in order to prevent a high unemployment rate, to protect the workers and to improve the living standard of the people (D.49) According to the law, the government is under the obligation of providing a job to its citizens. Tokol (2001:13) " The Turkish law explicitly says that the government has responsibility to employ its citizens as much as it can in leading industrial and socio-political enterprises.

It is said that humans do their best when the attitude is defined in terms of capacity of people. This means that there are desires and opportunities. Desires always define the best thing for a person. On the other hand, opportunities are the methods and choices of people which are genuinely made by them. (Elster,2007:199). Nowadays, one can say that one of the best work option is a post in the public sector. The significance of this is already depicted in the applications for the KPSS civil servant exams. As we can see in the table number 1, the number of people willing to pass this exam has increased showing the growing interest.

There are a dozen of good reasons why people in Turkey really want to work in the public sector. Some of them are as follows; lower chance to get a job in the private sector due to the 
augmentation of the competition, lower salary positions, the ambiguity of working terms in the private sector, growing unemployment rates caused by the crisis. We will profoundly articulate below what are the main reasons why people are indeed willing to work in the public sector.

\section{The process of hiring employees}

The main reason of running a business lies in making profit by it. The highest is the profit if the production costs are low and the quality of the product is superior to the average. (Akat, 2009:28) Moreover, public organizations are launched in order to serve a larger community. Those institutions are unified by the government that aims at a principle of social pragmatism and serving to community. (Sabuncuoglu, 2010:215)

In the process of hiring workers in the private sector, personal details of applicants, his or her $\mathrm{CV}$, field experiences are the most important as much as the successes once has done in order to accelerate the process. (Barutcugil, 2004:262) On the other hand, the main principle of hiring workers in a public business is to provide the equality for the applicants. (Bulutoglu, 2004:190)

The government of Turkey, during the first years of the of the republic, has installed a new work force hiring system based on the amendments of the 1924 law system. Yet it has been implemented in 1926. In the law system of 1926, according to the announcement of 93rd notification; the qualification, rights, duties, promotions and the salaries of the clerks are considered according to the regulations. In 1926, a new amendment has been announced which is considered to care about the clerk rights (Güler, 2005:213).

Clerks are selected by the public organizations according the the law n. 788. The law also details the qualities a future employee must possess. That means that a clerk is supposed to have completed his or her secondary education. If there is not a convenient person from among the ones holding a secondary school diploma, it is permitted to hire someone without a proper degree. This system was fully implemented solely in 1939. In 1939, a new law came out on "Civil servants and their monthly income" which has regulated the organization of exams. No examination is declared or required for those who are not qualified as a clerk. (Duran, 2006).

For many years, in Turkey, a system of institutional exams was used, but for the first time in history, in 1965, according to the law n. 657 a mixed system has been introduced. This law has been modified in 1984.

The new exam system was proposed by the newly formed State Personal Directorate. This new system was a forerunner of the coming centralized system which came into existence in 1999 only. (Güler, 2005:171-172).

To make it more simple to be a public servant in 1999 DMS or Devlet Memurluğu Sinav1 (Government Public Servants' Exam) has been launched. This centralized exam was renamed later on, the appellation Central Exam of Public Organizations or Kurumlar İçi Merkezi Eleme Sinavi (KMS) was used in 2001 and the Public Personal Selection Exam or Kamu Personel Seçme Sinavı (KPSS) since 2002. 
Table 1. Applicants trying the KPSS according to their degrees 2004-2014

\begin{tabular}{|c||c||c||c||c|}
\hline \multicolumn{1}{|c||}{ Years } & High School & $\begin{array}{c}\text { Associate } \\
\text { Degree }\end{array}$ & Undergraduate & Total \\
\hline 2004 & 1.092 .479 & 246.434 & 392.846 & 1.731 .759 \\
\hline 2006 & 1.379 .211 & 283.554 & 456.804 & 2.119 .569 \\
\hline 2008 & 1.483 .767 & 373.922 & 550.690 & 2.408 .379 \\
\hline 2010 & 1.812 .103 & 606.663 & 835.320 & 3.254 .086 \\
\hline 2012 & 1.877 .684 & 695.175 & 931.307 & 3.504 .166 \\
\hline 2014 & 1.683 .696 & 779.314 & 1.028 .032 & 3.491 .042 \\
\hline
\end{tabular}

References: www.dpb.gov.tr, www.osym.gov.tr, 05.04.2015

\section{Guaranteed work place - Continuous earnings}

Guaranteed work place means that the employee can be sure of being employed on a long run. (Gök, 2006:84).

A civil servant has to be punished or commit a serious crime in order to lose his or her post. If this does not happen, he or she has a guaranteed place until the day of his or her retirement from work. There is not a way to fire someone because of him or her being judged incapable. (Aygün, 2010:67).

This cannot be said about a private company. In the private sector, it is a must for an employee to progress and the person concerned can lose his or her job for various reasons.

The legal basis regarding the civil servants, the law n. 657 drafted in 1965 empowers the employees in five ways. These are the protection against the changing nature of the government, the status, of the employee, the permanence of the job and work place and the fact that the civil servant is protected by the law in case of a legal procedure by a third party. (Güler, 2005:176181).

Nowadays, the number of employees loosing their job is increasing. This means that the fearing of loosing his or her job is increasing, too. In many sectors, there is a clear uncertainty concerning the continuous nature of the work places. (Seçer, 2009:307).

A civil servant can lose his or her job only cases defined by the law. (Kayar, 2011:386). In reality, those working in the public sector lose their job if they commit a serious crime. This also means that their position is maintained even times of economical crises in the country. We can find this motive in the answers given by those opting for the public sphere: "I am afraid of loosing my job" or "I fear that I might be fired." (Seçer, 2009:313).

The examples showed above clearly demonstrate that the public sector is not only attractive for the unemployed, but also for those working somewhere else. 
The big economical changes might make the work force restless, this is why everywhere in the world people fear to lose their job, especially in times of crises whereas a permanent income is necessary for a decent life.

\section{Unemployment}

Unemployment is the difference between the number of unemployed and those willing to work. In our industrialized time, the unemployment is not derived from a personal deficiency or incapability but from the economical system itself. That means that there a lot of people with the intention ans ability to work but without the chance to get a job. Having said that unemployed is the one who unsuccessfully tries to find a job. (Ayvaz, 1990:15-16).

Ertürk presents the effects of unemployment on the unemployed as follows: (2004:331) "What is more difficult to realize? The fact that the value of your money is decreasing or the fact that you do not have money at all? The first situation is that of inflation, the second unemployment. Inflation means that your partially lose your capability of buying different items, unemployment means that you cannot buy anything. This shows that in the developing countries the fight against unemployment is much more important." In developed countries, unemployment is created by the dynamism and industrialization of the economy, whereas in the underdeveloped world, it is a particular question raised by the lack of capital. The very reason for the unemployment in those countries is a mismatch between the labor supply and the capital. This form of unemployment is structural and persistent. (Ayvaz, 1990:17-18).

In Turkey, the main reason for the existence of unemployment is the high number of economical crises. The situation is more volatile in Turkey since it has a special demographic structure: the unemployment rate is incredibly high among the youth. The number of the young unemployed is growing by each and every crisis. (Yaprak, 2009).

The unemployment is a pressing issue also because many of the ones without a permanent job have to look after relatives (children, wife, parents) and have certain responsibilities within the frame of a traditional family, to might lead them to a deep unease. (Ertürk, 2004:336-337).

During the last few years, Turkey's economic growth was spectacular contributing to a small decrease in the field of unemployment. In 2011, with 8,5\%, Turkey was placed second after China in the list ranking the growth of the GDP. That means that in that particular year the economical growth of the country bypassed that of the EU or OECD countries. (www.milliyet.com.tr, 02.03.2015). This is the main cause behind the decrease of unemployment as shown in the table n. 2 .

In every country, unemployment is one of the most important problems of economy. It is foreseeable that it would also remain to be one of them. Even though it would stay with, the workers develop different strategies to fight it back in their personal lives.

The new Turkish exam system introduced in 1999 has at least the virtue of championing the equality of chances, meaning that the "gates of the public sector are open" for the ones who are ready for working for it. 
Table 2. Unemployment Rate

\begin{tabular}{|c|c|c|c|c|c|c|c|c|c|c|c|c|}
\hline & 2003 & 2004 & 2005 & 2006 & 2007 & 2008 & 2009 & 2010 & 2011 & 2012 & 2013 & 2014 \\
\hline Avustralia & 5,93 & 5,40 & 5,03 & 4,79 & 4,38 & 4,23 & 5,56 & 5,21 & 5,08 & 5,22 & 5,66 & 6,07 \\
\hline Belgium & 4,29 & 5,49 & 5,63 & 5,25 & 4,86 & 4,13 & 5,30 & 4,82 & 4,57 & 4,86 & 5,34 & 5,62 \\
\hline Canada & 7,58 & 7,19 & 6,76 & 6,33 & 6,05 & 6,14 & 8,35 & 8,06 & 7,53 & 7,29 & 7,08 & 6,91 \\
\hline France & 8,46 & 8,85 & 8,88 & 8,83 & 8,01 & 7,39 & 9,12 & 9,28 & 9,17 & 9,83 & 9,86 & 9,86 \\
\hline Germany & 9,64 & 9,79 & 11,17 & 10,25 & 8,66 & 7,53 & 7,74 & 7,07 & 5,83 & 5,38 & 5,23 & 4,98 \\
\hline Greece & 9,79 & 10,59 & 9,99 & 9,01 & 8,40 & 7,76 & 9,62 & 12,72 & 17,87 & 24,44 & 27,47 & 26,49 \\
\hline Israel & 10,71 & 10,37 & 8,99 & 8,40 & 7,32 & 6,10 & 7,54 & 6,64 & 5,60 & 6,85 & 6,21 & 5,91 \\
\hline Russia & 8,63 & 8,16 & 7,56 & 7,17 & 6,13 & 6,36 & 8,38 & 7,48 & 6,50 & 5,46 & 5,49 & 5,16 \\
\hline Japan & 5,26 & 4,72 & 4,42 & 4,14 & 3,84 & 3,99 & 5,07 & 5,05 & 4,58 & 4,35 & 4,03 & 3,59 \\
\hline Korea & 3,57 & 3,68 & 3,73 & 3,47 & 3,25 & 3,17 & 3,65 & 3,73 & 3,41 & 3,23 & 3,13 & 3,54 \\
\hline New Zealand & 4,78 & 4,05 & 3,83 & 3,85 & 3,67 & 4,17 & 6,13 & 6,53 & 6,53 & 6,90 & 6,20 & 5,65 \\
\hline Spain & 11,49 & 10,67 & 9,15 & 8,45 & 8,23 & 11,24 & 17,86 & 19,86 & 21,39 & 24,79 & 26,06 & 24,44 \\
\hline Switzerland & $\ldots$ & $\ldots$ & $\ldots$ & $\ldots$ & $\ldots$ & $\ldots$ & $\ldots$ & 4,55 & 4,04 & 4,18 & 4,39 & 4,54 \\
\hline Turkey & $\ldots$ & $\ldots$ & $\ldots$ & 8,75 & 8,89 & 9,73 & 12,58 & 10,68 & 8,81 & 8,17 & 8,74 & 9,88 \\
\hline England & 4,97 & 4,70 & 4,76 & 5,37 & 5,28 & 5,63 & 7,54 & 7,79 & 8,04 & 7,89 & 7,53 & 6,11 \\
\hline United States & 5,99 & 5,53 & 5,07 & 4,62 & 4,62 & 5,78 & 9,27 & 9,62 & 8,95 & 8,07 & 7,38 & 6,17 \\
\hline EU(28) & $\ldots$ & $\ldots$ & 8,90 & 8,17 & 7,16 & 7,00 & 8,91 & 9,58 & 9,62 & 10,45 & 10,79 & 10,13 \\
\hline
\end{tabular}

Reference: https://data.oecd.org/unemp/unemployment-rate.htm\#indicator-chart

\section{Salary}

The salary recognizes the physical or mental efforts one has done while working. The salaries in the private sector are defined according to the possibilities on the market. The management of a private company is free to fix the salaries after contemplating the market and the labor force market as well. Enterprises are aimed at increasing the work efficiency without raising to much the income of the workers. (Tokol, 2001:163).

This situation might fit the taste of the management, but it is hardly good for the workers. In Turkey today, the lowest salary in the public sector is much higher than the lowest salary in the private sector. The prove this, we have to have a look at the sum of the official minimum wage paid the latter one. The tendencies show that in recent times with diminution of the size of the enterprises the salary decreases as well. Even though the average salary in the public sector is not high, as it is guaranteed, many would opt for a post in the public.

If we try to define the difference between the lowest incomes in the two sectors, we find that the lowest wage in 2003 in the private sector was 306 Turkish lira (www.csgb.gov.tr ,02.04.2015), at the same time the least paid civil servant got 422,54 Turkish lira. (www.kamusen.org.tr, 02.04.2015) In 2015, the lowest salary of a civil servant is 2.114 Turkish lira (www.sabah.com.tr,29.03.2015) whereas the official minimum wage in the private sector is as low as 949,07 Turkish lira. (www.csgb.gov.tr, 05.04.2015) 


\section{Working conditions}

The working conditions are said to be better in the public sphere since the main interest of a private company is profit. This is why at many occasions, companies do not care about the health of their workers. A good example of that is the events that had happened in the Tuzla Shipyard in 2008 that lead to a loss in human lives. It is interesting to examine how the irresponsible behavior of the management can be blamed for the accident (Arslan, Durukanoğlu, 2009) "Metin Kalkavan, the head of the Naval Trade Camber (Deniz Ticaret Odas1, DTO) said "we are not produced iron, we are not producing textile, we produce ships. The workers have to bear in mind that they can die while working." as if death was a natural thing.

On the 11th March 2012, in a fire occurring in Esenyurt 11 workers have been killed. The colleagues of those deceased in the incident explained the working condition in the following manner: (Zaman,2012) "All the victims were guest workers. Their families live in other parts of the country. The contractors did not do anything to make the working conditions better. Next time would we stay under tents?"

The annual report of the International Labor Organization (ILO) puts Turkey on the list of countries notorious for providing poor working conditions. They state that there are major problems as far as the taking into consideration of the security norms and regulations are concerned. (MMO,2012:147). According to the statistics of the ILO, in every 15 seconds there is an accident at work causing the death or the injury of a worker. In Turkey, on a yearly basis, 1200 workers die, 1400 more get disabled. With these sad statistics Turkey is the first in Europe and third in the World! (Illki,2012).

One might say that for sure there are many countries where much more people die at work, but they do not prepare that accurate statistics or hide the reality. We can also say that in the past few years the number of work place accidents is slowly decreasing in Turkey.

Civil servants have prescribed working hours. Those working in the private sector work under difficult conditions and are exposed to the wills and desires of the management. In the 3rd table, on can see that Turkey is one among the OECD member states where the working hours are the longest in the 2006-2013 period. There is not a law governing this at the private enterprises. In fact, workers are forced to accept all the conditions imposed by their bosses in order to keep their job. 
Table 3. Average usual weekly hours worked on the main job

\begin{tabular}{|c|c|c|c|c|c|c|c|c|}
\hline Country & 2006 & 2007 & 2008 & 2009 & 2010 & 2011 & 2012 & 2013 \\
\hline Australia & 36,738979 & 36,856101 & 36,836048 & 36,421326 & 36,321317 & 36,348215 & 36,401095 & 36,257463 \\
\hline Austria & 39,170757 & 38,933303 & 38,492043 & 38,059584 & 37,780272 & 37,760769 & 37,605075 & 37,184155 \\
\hline Belgium & 36,794734 & 37,079152 & 36,761447 & 36,771727 & 36,915255 & 36,83673 & 36,943155 & 37,242192 \\
\hline Canada & & & & & & & & 0 \\
\hline Chile & 43,92874 & 43,696636 & 43,805447 & 43,369044 & 42,725561 & 42,673517 & 42,675863 & 42,457252 \\
\hline Czech & & & & & & & & \\
\hline Republic & 41,702076 & 41,677377 & 41,662859 & 41,386864 & 41,168292 & 41,046791 & 40,838247 & 40,47339 \\
\hline Denmark & 35,348419 & 34,365398 & 34,10386 & 33,729679 & 33,631796 & 33,658034 & 33,579977 & 33,612797 \\
\hline Estonia & 39,644491 & 39,557876 & 39,446915 & 38,721502 & 38,733865 & 38,667595 & 38,808186 & 38,832472 \\
\hline Finland & 38,099754 & 37,484488 & 37,539698 & 37,296269 & 37,294128 & 37,244229 & 37,10817 & 36,906825 \\
\hline France & 38,097286 & 38,097981 & 38,129652 & 38,047257 & 38,038025 & 38,033482 & 37,921268 & 37,51147 \\
\hline Germany & 35,605923 & 35,500808 & 35,578328 & 35,679218 & 35,682817 & 35,539577 & 35,549178 & 35,31468 \\
\hline Greece & 42,735403 & 42,470764 & 42,444169 & 42,490929 & 42,295987 & 42,123748 & 42,024106 & 42,116731 \\
\hline Hungary & 40,303222 & 40,227273 & 40,087722 & 39,84612 & 39,752103 & 39,45942 & 39,433914 & 39,544383 \\
\hline Iceland & 41,653217 & 41,642424 & 41,227307 & 39,442283 & 39,088657 & 39,701873 & 39,437571 & 39,585155 \\
\hline Ireland & 36,582679 & 36,391089 & 36,092091 & 35,214705 & 34,974134 & 34,883809 & 35,042434 & 35,373867 \\
\hline Israel & 41,040055 & 41,401824 & 41,031859 & 40,609894 & 40,793035 & 40,855589 & 41,065638 & 40,704958 \\
\hline Italy & 38,531734 & 38,44855 & 38,242456 & 37,998801 & 37,789313 & 37,508515 & 37,058582 & 36,93851 \\
\hline Japan & & & & & & & & 0 \\
\hline Korea & 48,530558 & 47,675665 & 46,648479 & 46,551921 & 45,85522 & 44,632304 & 45,327864 & 43,778249 \\
\hline Luxembourg & 37,270826 & 36,696102 & 36,726221 & 37,151501 & 37,153274 & 37,01358 & 37,195304 & 37,132894 \\
\hline Mexico & 40,56777 & 40,415227 & 40,455902 & 40,303825 & 43,131004 & 43,25957 & 42,806668 & 43,00552 \\
\hline Netherlands & 30,86487 & 30,77393 & 30,751236 & 30,595624 & 30,62216 & 30,518187 & 30,332777 & 29,993395 \\
\hline $\begin{array}{l}\text { New } \\
\text { Zealand }\end{array}$ & 37,973608 & 37,744117 & 37,643195 & 37,355855 & 37,424036 & 37,418172 & 37,267926 & 37,545453 \\
\hline Norway & 34,223512 & 34,255483 & 34,268715 & 34,191374 & 34,097065 & 34,144037 & 34,261314 & 34,240939 \\
\hline Poland & 40,916841 & 41,009228 & 40,970458 & 40,744306 & 40,587975 & 40,545215 & 40,671146 & 40,713386 \\
\hline Portugal & 39,084586 & 38,975126 & 39,038747 & 38,943503 & 38,952616 & 39,153775 & 39,158034 & 39,440116 \\
\hline $\begin{array}{l}\text { Slovak } \\
\text { Republic }\end{array}$ & 40,988897 & 41,008359 & 40,943583 & 40,761555 & 40,567887 & 40,55462 & 40,739158 & 40,689809 \\
\hline Slovenia & 40,341105 & 40,33359 & 40,448451 & 39,785167 & 39,365302 & 39,470058 & 39,773538 & 39,591035 \\
\hline Spain & 39,407997 & 39,309632 & 39,144344 & 38,845649 & 38,667771 & 38,452049 & 38,165513 & 37,994254 \\
\hline Sweden & 36,735116 & 36,453563 & 36,37532 & 36,2923 & 36,336025 & 36,326793 & 36,366855 & 36,326868 \\
\hline Switzerland & 35,416985 & 35,550259 & 35,342733 & 35,125543 & 35,174421 & 35,237874 & 35,142207 & 35,046037 \\
\hline Turkey & 52,335878 & 51,048875 & 50,512668 & 49,375147 & 49,266117 & 48,855397 & 48,381272 & 47,860752 \\
\hline $\begin{array}{l}\text { United } \\
\text { Kingdom }\end{array}$ & 36,922432 & 36,990414 & 36,913383 & 36,552742 & 36,419022 & 36,407818 & 36,364452 & 36,507723 \\
\hline $\begin{array}{l}\text { United } \\
\text { States }\end{array}$ & & & & & & & & \\
\hline Brazil & 39,715029 & 39,751804 & 39,733118 & 39,667502 & & 39,747054 & 39,504283 & \\
\hline $\begin{array}{l}\text { Russian } \\
\text { Federation }\end{array}$ & & & & & & & & \\
\hline Sout Africa & & & 45,414125 & 44,702206 & 44,501645 & 44,528005 & 44,244164 & 43,974411 \\
\hline
\end{tabular}

Reference: www.oecd.org, 02.04.2015

\section{Social status}

Social status is understood as the rights and responsibilities of a group of people as well as they position or rank according to other groups. (Yozgat, 1997:107).

Everyone has a certain social status. Everyone has a certain situation within the society he lives in as societies are not composed in random manner. Societies are organized on the basis of the elements constituting it. (Fischter, 2009:35). 
Everyone has different statuses within the same society. For example one can be a father, a husband and employee at work place at the same time, he or she can -at a given level- lead other employees, as far as the national level is concerned, he is a citizen of that country. All these are different social statuses. (Gün, 2009).

Social status explains the prestige and the valuer of the individual for the rest of his or her society. If his or her role to be played within the frame of the given society is important, he or she holds there a high social status. (Yozgat, 1997:107).

In general, the position of a civil servant is considered as a high social status. Societies show respect towards the ones working in the public sector as they think that such a job is pleasant and fits the desires of a worker.

\section{Leave}

There is a certain differences between the number of the days of leave and vacations in the public and the private sectors. According to the law n. 657 the government guarantees the following amount of days to the civil servants: during the first ten years of work 20 days, after that 30 days. A maximum of 2 days can be added to this for those commuting between their work places and homes. According to the law n. 4857 those working in the private sector have the right to 14 days during the first five years, five and fifteen years of experience let you to spend 20 days away of your office, at least 15 years spent working entitles you to get 26 days of leave. Considering this information, the civil servants have more vacations.

The civil servants can use their leaves easier than the ones working in the private sector. In the private sector, many companies force their employees to take unpaid leaves. This would be impossible in the public sector.

\section{Career}

Carrier means "the personal advancement of a worker from his or her first year until the end of his professional life.” (Turgut Özal Üniversitesi KARMER,2011:10).

The person concerned advances in the hierarchy and with every step he or she gets closer and closer to high ranking positions. (Baycan,2005:54).

Someones career cannot be influenced by laws in the private sector. Every private enterprise has its own career scheme. The career of the civil servants is regulated by laws. In Turkey the Law on Civil Servants or Devlet Memurları Kanunu (DMK) which describes precisely what kind of degrees and deeds are necessary to advance in one's career, this gives always the chance to the civil servant to improve and climb the hierarchy. (657 DMK,m.3).

In the present Turkish civil servant career system advancement is made step by step, meaning that the person has to serve a given time period (one year), to get the necessary stamps, this advancement can be called a gradual advancement. A civil servant can progress as well in a vertical way in the system, this also spells more responsibilities and work to do. According to the law n. 657 and its paragraph n. 68. A civil servant has to serve at least three years and to have all the necessary qualifications to be able to reach a high position (third level). (Şaylan, 2000:37). 
This progression is not open to everybody working in the public sector, only the civil servants and some similar subgroups have access to it. So, ordinary workers and those working on the basis of a contract cannot progress in the above-described manner. (Güler, 2005:225).

\section{Conclusion}

Human beings in Turkey as well as in other parts of the World out of their inherent nature want to live the best possible way. Working in the public sector in Turkey slowly became attractive not only for the ones having low degrees of education but also for the well versed. Today, it is the goal of many university students.

Finding a stable job became a preference since unemployment is high and economical crises are frequent. As the private sector becomes more and more fragile, parents advise their children to opt for the public sector causing a heavy growth in the number of civil servants.

It is nearly a fact that this growth would continue in the future. Since 1999 the exam then called DMS, later renamed KPSS let a larger number of applicants to get to the civil service.

After all the most important reason behind choosing the public sector is a security it guarantees for its employees. Because of inner problems, sometimes, private companies offer lower and lower wages. In Turkey, the salary one can obtain in the civil service is fixed, it is also known how much it can increase year by year. The salaries proposed in the public sector is linked to the economical situation of the country, it is always sufficient to live a decent life.

When civil servants go shopping they might say to the shopkeeper: "I am a civil servant, please, give me a discount", the shopkeeper would answer: "I would like to be one, too". It means that being a civil servants is convenient not only in periods of crisis, but also at times when economic growth is there.

If we consider the situation in Turkey and in the World, it seems that number of people opting for the public sector would not decrease but increase. For civil servants, the Turkish state acts as an employer. On one hand, certain Turkish governments privatize a part of the public sector, this way they distance themselves from the position of an employer, but on the other hand the growing number of people willing to work in the public sector would make this sector even stronger.

\section{References}

1. Aysen Tokol, “ Endüstri İlişkileri ve Yeni Gelişmeler’, Vipaş Yayınları, Bursa, 2001

2. Barış Seçer, "İş Güvencesizliği: Türleri, Başa Çıkma Süreci, Belirleyicileri ve Sonuçları', Editörler: Aşkın Keser, Gözde Yılmaz ve Şenay Yürür, Çalışma Yaşamında Davranış Güncel Yaklaşımlar, 1.Baskı, Umuttepe Yayınları, Kocaeli

3. Birgül Ayman Güler, “Kamu Personeli Sistem ve Yönetim”, İmget Kitabevi, Ankara, 2005

4. Emin Ertürk, "Küresel Ekonomide Makroekonomik Analize Giriş’, 2.Bask1, Alfa Aktüel Yayınları, İstanbul, 2004

5. Fazıl Yozgat, "Sosyal Değişme Faktörleri', Ankara, 1997

6. Gencay Şaylan, Kamu Personel Yönetiminden İnsan Kaynakları Yöntemine Geçiş, Tesev Yayınları, İstanbul, 2000 
7. İsmet Barutçugil, “ Stratejik İnsan Kaynakları Yönetimi”, Kariyer Yayınları, İstanbul, 2004

8. Jon Elster, "Sosyal Davranışı Açıklamak”, Çevirenler: Olcay SEVİMLİ, Macide Ö.KARADUMAN, Phoenix Yayınları, Ankara, 2007

9. Joseph Fischter, 'Sosyoloji Nedir', Çeviren: Nilgün Çelebi, 9.Baskı Anı Yayınları, Ankara, 2009

10. KARMER (Kariyer Planlama Uygulama ve Araştırma Merkezi ), “Kariyer Planlama ve Geliştirme El Kitabı',, Turgut Özal Üniversitesi, Ankara, 2011

11. Kenan Bulutoğlu, "Kamu Bütçesi Kamu Harcamaları Kamu Borçları', Batı Türkeli Yayınları, İstanbul, 2004

12. MMO (Makine Mühendisleri Odası), “İş Sağlığı ve İş Güvenliği”, MMO Yayınları: 590, Ankara, 2012

13. Nihat Kayar, "Kamu Personel Yönetimi'”, 3.Baskı Ekin Yayınları, Bursa, 2011

14. Ömer Akat, "Uygulamaya Yönelik İşletme Politikası ve Stratejik Pazarlama”, 4.Bask1 Dora Yayınları, Bursa, 2009

15. Sibel Gök, “21. Yüzyılda İnsan Kaynakları Yönetimi’”, Beta Yayınları, İstanbul, 2006

16. Zehra Aygün, 'Kamu Yönetimi', 2.Baskı Kum Saati Yayınları, İstanbul, 2010

17. Zerrin Ayvaz, "Türkiye'de İstihdam ve İşsizlik Sorunları',(Master Thesis), İstanbul, 1999

18. Zeyyat Sabuncuoğlu, “İşletmelerde Halkla İlişkiler”, 10.Baskı Alfa Aktüel Yayınları, Bursa, 2010

19. 657 Devlet Memurları Kanunu

20. Web Source

21. Cihangir Baycan, "Polis Memurları Rütbe ve Yükselme Sistemi'”, 2005, Page.54, http://www.pa.edu.tr/APP_DOCUMENTS/D478B2AD-3813-4555-9629-

6332F8CF8D33/cms_statik/_dergi/2005/2/51-68.pdf, 31.01.2015

22. Cengiz Gün, "Kendini Gerçekleştirme Statü Vizyon",

23. http://www.caginpolisi.com.tr/eski_sitemiz/65/35-36-37.htm, 31.02.2015

24. Erkan Arslan, Kenan Durukanoğlu: "Tuzla Tersaneler Bölgesi Gerçeği”, 2009, http://www.metalurji.org.tr/dergi/dergi150/d150_2730.pdf, 01.01.2015

25. Vedat İlki, '1 Mayıs'a Bir Gün Kala',

26. http://www.alitezel.com/index.php?sid=yazi\&id=5360, 01.02.2015

27. Zaman Gazetesi, “Büyümede Tek Rakibimiz Çin', 2010,

28. http://www.zaman.com.tr/ekonomi_buyumede-tek-rakibimiz-cin_1267765.html, 01.02 .2015

29. Zaman Gazetesi, “Esenyurt'ta İnşaatta Yangın: 11 İşçi Hayatını Kaybetti’, 2012, http://www.zaman.com.tr/gundem_esenyurtta-insaatta-yangin-11-isci-hayatinikaybetti_1257644.html, 01.02.201 $\overline{5}$

30. www.milliyet.com.tr, 02.03.2015

31. www.oecd.org, 02.04.2015

32. www.kamusen.org.tr, 02.04.2015

33. www.csgb.gov.tr, 05.04.2015

34. www.dpb.gov.tr, 05.04.2015

35. www.osym.gov.tr, 05.04.2015 